https://doi.org/10.15407/frg2021.05.435

UDC 581.02.132

\title{
STRUCTURAL AND FUNCTIONAL DEPENDENCE OF PSII ACTIVITY UNDER OXIDATIVE STRESS
}

\author{
J. JAFAROVA ${ }^{1}$, R. GANIEVA ${ }^{1}$, L. MAMMADOVA ${ }^{2}$, R. AGALAROV ${ }^{2}$, R. GASANOV ${ }^{2}$ \\ ${ }^{1}$ Institute of Botany, National Academy of Sciences of Azerbaijan \\ Baku, AZ 1073, Azerbaijan \\ e-mail: j.jafarova@yahoo.com \\ ${ }^{2}$ Biotechnology Laboratory, Department of Biophysics and Molecular Biology \\ Baku State University, Baku AZ 1021, Azerbaijan
}

The action of methyl viologen (MV) on pumpkin leaves (Cucurbita pepo L.) increased the content of reactive oxygen species (ROS) that caused disruption of the PSII electron transport chain. After the treatment by MV the seedlings were treated by protein synthesis inhibitor - chloramphenicol (CAP). The millisecond delay fluorescence of chlorophyll (Chl) $a$ induction curves analysis (msec-DF Chl $a$ ) is shown the change of intensity of phase of msec-DF Chl $a$, possible in result of suppression $\mathrm{D}_{1}$ protein de novo formation. The changes of proteins profiles especially of PSII polypeptides content in chloroplasts in dependence on action of methyl viologen and chloramphenicol were observed. The high correlation between changes of PSII polypeptides and changing of stationary phase of msec-DF Chl $a$ were shown.

Key words: Cucurbita pepo L., oxidative damage, millisecond delay fluorescence of Chl $a$, reactive oxygen species, methylviologen.

The reaction centers of PSI and PSII in chloroplast thylakoids are known to be a main site of ROS generation under oxidative stress [13] that induced a significant damage to cell biological structures and physiological-biochemical processes in them [2]. ROS, accumulating in chloroplasts [12] affects first to PSII and its main manganese complex- $\mathrm{Mn}_{4} \mathrm{O}_{5} \mathrm{Ca}$-cluster $[1,15]$. The fall of PSII activity is regards in result of balance disturbance between its restoration and damage since in intact cells these processes are take place simultaneously [16, 19].

The oxygen of main triplet state $\left({ }^{3} \mathrm{O}_{2}\right)$ is excited to singlet state $\left({ }^{1} \mathrm{O}_{2}\right)$ by chlorophyll of reaction centers of triplet excited state $\left({ }^{3} \mathrm{P} 680^{*}\right)$ [18]. The target of ROS is known to be $\mathrm{D}_{1}$ protein that is one of subunit of PSII reaction center ( $\mathrm{RC})$, that catalyzed water splitting and realized primary functions of charge separation and RC chlorophyll electron separation [8]. The $\mathrm{D}_{1}$ protein degradation at definite conditions may be triggered by long lived oxidative forms such as $\mathrm{P} 60^{+}$(first donor and $\mathrm{Tyr}-\mathrm{Z}^{+}$) and take place at oxygen absence [10]. Degradation and resynthesis of $\mathrm{D}_{1}$ protein is a process significantly faster compare to other thylakoid proteins and it is

Citation: Jafarova J., Ganieva R., Mammadova L., Agalarov R., Gasanov R. Structural and functional dependence of PSII activity under oxidative stress. Fisiol. rast. genet., 2021. 53, № 5, pp. 435-443. https://doi.org/10.15407/frg2021.05.435 
a reason of impossibility to detect of new synthesized proteins to restoration of photosynthetic activity $[9,11,14,16]$. The inhibitors of protein synthesis are widely used in this studies. Chloramphenicol is one of them which connection to great subunit of $70 \mathrm{~S}$ ribosome has blocked its peptidyl-transferase activity [11].

The aim or our work was the investigation of damage mechanisms of PSII electron transport chain under increased content of ROS and its connection with $\mathrm{D}_{1}$ protein degradation.

\section{Materials and methods}

The investigation objects were pumpkin leaves (Cucurbita pepo L.) from second tier of two week seedlings, grown at $22{ }^{\circ} \mathrm{C}$ and $80 \%$ humidity, and isolated from them chloroplasts. To create an oxidative stress in leaves and chloroplasts 50 and $100 \mu \mathrm{M}$ methyl viologen (MV) $\left(1,1^{\prime}\right.$-dimethyl-4,4'bipyridinium) that is known to create a reactive oxygen species, and $10 \mathrm{mg} / \mathrm{ml}$ inhibitor of protein synthesis chloramphenicol (CAP) were used during comparative analysis.

Chloroplast preparation. The plant leaves were homogenized in buffer contained $40 \mathrm{mM}$ HEPES (pH 7.4), $0.3 \mathrm{M}$ sorbitol, $10 \mathrm{mM} \mathrm{MgCl}_{2}, 1 \mathrm{mM}$ EDTA, $1 \mathrm{M}$ glycine-betaine. The suspension was centrifuged during $5 \mathrm{~min}$ at $1100 \mathrm{~g}$. The sediment was treated by osmotic buffer $10 \mathrm{mM}$ HEPES $(\mathrm{pH}$ 7.4), $5 \mathrm{mM}$ sorbitol and $10 \mathrm{mM} \mathrm{MgCl}_{2}$ to obtain suspension. The suspension was precipitated at $2000 \mathrm{~g}$. Obtained final sediment was suspended in buffer containing $10 \mathrm{mM}$ HEPES (pH 7.4), $0.5 \mathrm{M}$ sorbitol, $10 \mathrm{mM} \mathrm{MgCl}_{2}$ and $5 \mathrm{mM} \mathrm{NaCl}$. Isolation of chloroplasts at all steps was carried out at $4{ }^{\circ} \mathrm{C}$ under weak green illumination [8].

Method of millisecond delay fluorescence of chlorophyll $a$. The functional state of photosynthetic apparatus was evaluated by millisecond delay fluorescence (msec-DF Chl $a$ ) method. Msec-DF of Chl $a$ was measured with phosphoroscope in such way that $0.3 \mathrm{~ms}$ excitation light pulse was following by $1.25 \mathrm{~ms}$ of dark and $0.3 \mathrm{~ms}$ of registration of the delayed light emission The method of msec-DF Chl $a$ makes it possible fast evaluation of plant stability and weak sites in photosynthetic chain under stress conditions [6].

The method of polyacrylamide gel electrophoresis. Electrophoresis was fulfilled in «Mini Protean» (Bio-Rad) and while using in finished gel «mini-protean TGX stain-free precast» which does not contain SDS. Running buffer ( $\mathrm{pH} \mathrm{8.3)} \mathrm{contained} 25 \mathrm{mM}$ Tris- $\mathrm{HCl}, 192 \mathrm{mM}$ glycine and

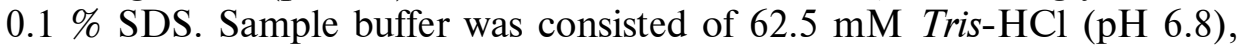
$25 \%$ glycerol, $2 \%$ SDS, $0.01 \%$ bromophenol blue. Before the use $950 \mu 1$ of buffer was mixed with $50 \mu 1 \beta$-merkaptoethanol. The prepared chloroplast samples were mixed with buffer samples in 1:1 ratio and placed to the gel plate. The separation of proteins was fulfilled during 35-45 min at $200 \mathrm{~V}$ maximum. $0.2 \mathrm{~g}$ of Coomassie (Brilliant) Blue G-250, $80 \mathrm{ml}$ of methanol and $20 \mathrm{ml}$ of acetic acid were used for polypeptides staining.

Statistical analysis. All data are presented as mean \pm standard deviation of triplicate analyses of each sample. Data were analyzed by Column Statistics analysis using the Origin Pro 9 Software (Origin Corporation, 2009). 


\section{Results and discussion}

The activity of electron transport chain (ETC) of PSII was evaluated by changes of induction transients of msec-DF of Chl $a$ that in intact system are in tight connection with metabolic processes and regulated by cell at accordance with its energetic requirements.

The activity of PSII ETC in incubated with methyl viologen leaves decreased. The first phase (f.ph.) intensity after $4 \mathrm{~h}$ incubation was equal to $53 \%$ activity in control. Slow phase (sl.ph.) after $2 \mathrm{~h}$ adaptation decreased at $62 \%$ and after $4 \mathrm{~h}$ adaptation restored to $53 \%$. Chloramphenicol action under leaves infiltration also suppressed an activity of ETC PSII. After $4 \mathrm{~h}$ adaptation an activity of f.ph. was equal to $53 \%$, and sl.ph. $-73 \%$ of control.

Under action of CAP to leaves after their infiltration in methyl viologen solution an effect of CAP was abolished. The sharp fall of activity as f.ph. and so sl.ph. in PSII ETC after $4 \mathrm{~h}$ of adaptation relatively to action of CAP and MV separately (Fig. 1 and 2) was observed. The restoration under CAP after $4 \mathrm{~h}$ does not change of state s.ph fluorescence that indicated to preservation of oxidation-restoration equilibrium in connection to MV action (Table 1).

The densitometric analysis of profiles of thylakoid polypeptides has shown that quantitative and quality changes of them depended on stress action (Fig. 3a) and correlated with phases of msec-DF characteristics. The polypeptides profile in control chloroplasts is presented by zones with m.m. 60-66 kDa (monomer PSI), shoulder at $49 \mathrm{kDa}$ with two-humped peaks at $47-43 \mathrm{kDa}$ (corresponding to dimer LHPC of PSII). The clear peak at $30-32 \mathrm{kDa}$ zone belongs to core of PSII and shoulder at $27 \mathrm{kDa}$ and zone at $23-25 \mathrm{kDa}$ corresponding to LHPC monomer (see Fig. 3b, 1). Twohumped peak at $38-39 \mathrm{kDa}$ zone connected probably with PSII core.

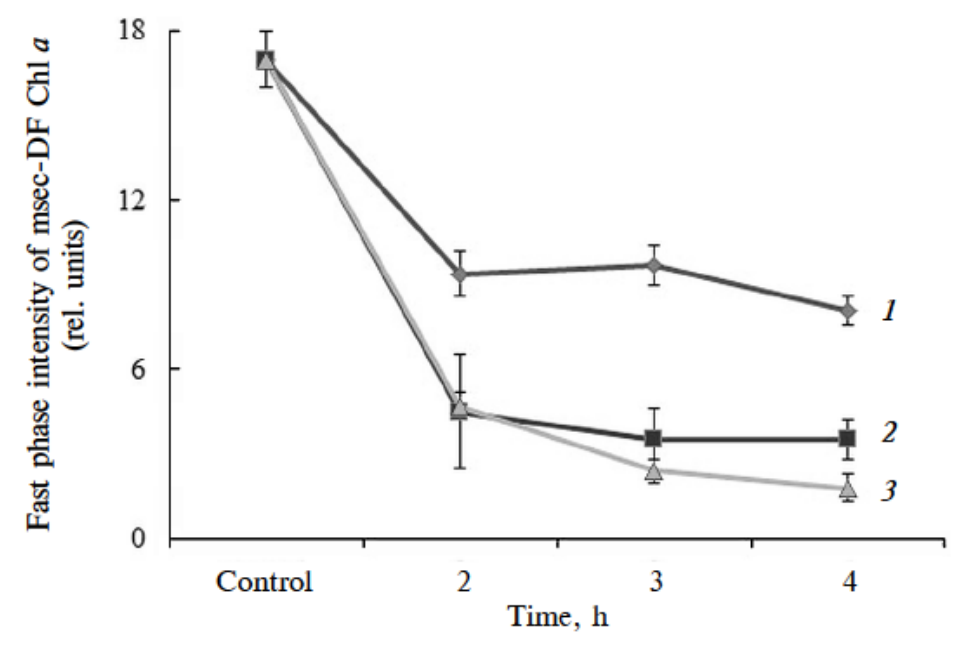

Fig. 1. Changes of fast phase (f.ph.) intensity of induction curve msec-DF of Chl $a$ in pumpkin leaves. Here and in Fig. 2:

1 - treatment $5 \mathrm{~min} 10 \mathrm{mg} / \mathrm{ml}$ chloramphenicol (CAP) solution after that 2, 3, 4 hours restoration of leaves; 2 - treatment $5 \mathrm{~min} 100 \mu \mathrm{M}$ methyl viologen (MV) solution after that 2, 3, $4 \mathrm{~h}$ restoration of leaves; 3 - after treatment $5 \min 100 \mu \mathrm{M}$ with MV solution, leaves were washed and after 15 min treated $5 \mathrm{~min}$ with $10 \mathrm{mg} / \mathrm{ml}$ CAP solution, and $2,3,4 \mathrm{~h}$ restoration $(\mathrm{MV} \rightarrow \mathrm{CAP})$ 


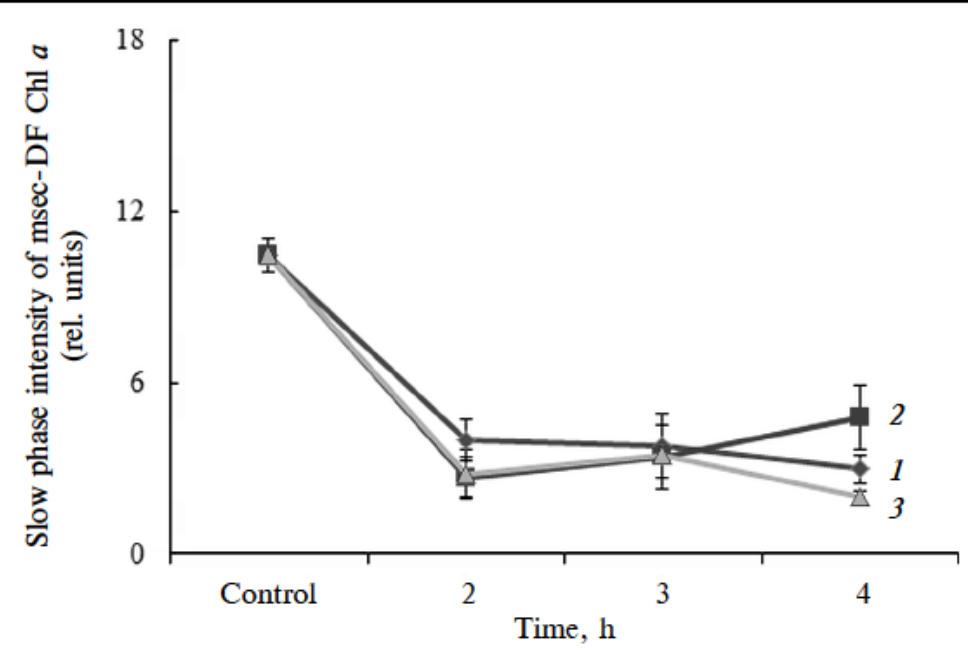

Fig. 2. Changes of slow phase (sl.ph.) intensity of induction curve msec-DF of Chl $a$ in pumpkin leaves

Table 2 shows the change in the average density of the $43-47 \mathrm{kDa}$ protein zone corresponding to dimer LHPC of PSII, and the $30-32 \mathrm{kDa}$ protein zone associated with the PSII core. Quantitative changes in the polypeptide profiles and the ratio of protein zones observed under the action of MV and CAP are compatible with the action of other oxidants. So the effect of $\mathrm{NaCl}$ was shown in a change in the ratio of chlorophyllprotein complexes and polypeptides in the zone of 38-49 $\mathrm{kDa}$ and in the zone of $25-30 \mathrm{kDa}$, which quantitatively increased under the action of the thylakoid membrane stabilizer Polistimulin K. Changes in the polypeptide profiles suggest their role in the protection of the thylakoid membrane, which is confirmed by studies of fluorescence characteristics $[4,5,7]$.

Under action of MV to leaves during $5 \mathrm{~min}$ on induction curve of msec-DF Chl $a$ the sharp change in slow phase of fluorescence probably connected with disturbance by ROS oxidation-restoration equilibrium between donor and acceptor sides (see Fig. 3b, 2). Toxic action of MV may be cause by its action on photochemical reactions in chlorophyll-protein complexes due its damage. This is confirmed by analysis that point out of significant changes in polypeptide profiles.

Action of MV during 5 min leads to significant changes in protein spectrum. The polypeptides at $30-32 \mathrm{kDa}$, charactering of $\mathrm{D}_{1}$ protein

TABLE 1. Changes of stationary phase (relative units) of induction curve of msec-DF Chl a in pumpkin leaves: Control - untreated green leaves; $M V$ - treatment 5 min $100 \mu M$ methyl viologen (MV) solution, than 2, 3, $4 \mathrm{~h}$ restoration of leaves; CAP - treatment $5 \mathrm{~min} 10 \mathrm{mg} / \mathrm{ml}$ chloramphenicol (CAP) solution, than 2, 3, 4 hours restoration of leaves; $M V \rightarrow C A P-$ after treatment $5 \mathrm{~min} 100 \mu \mathrm{M} \mathrm{MV}$ solution, leaves were washed and after $15 \mathrm{~min}$ treated 5 min with $10 \mathrm{mg} / \mathrm{ml}$ CAP solution, than 2, 3, 4 hours restoration

\begin{tabular}{l|c|c|c|c}
\hline Time (hours) & Control & MV & CAP & MV $\rightarrow$ CAP \\
\hline 2 & $0.9 \pm 0.04$ & $2.2 \pm 0.16$ & $1 \pm 0.06$ & $2.3 \pm 0.16$ \\
3 & $0.9 \pm 0.04$ & $2.7 \pm 0.3$ & $1.1 \pm 0.07$ & $1.5 \pm 0.01$ \\
4 & $0.9 \pm 0.04$ & $3 \pm 0$ & $1 \pm 0.06$ & $1.4 \pm 0.05$ \\
\hline
\end{tabular}




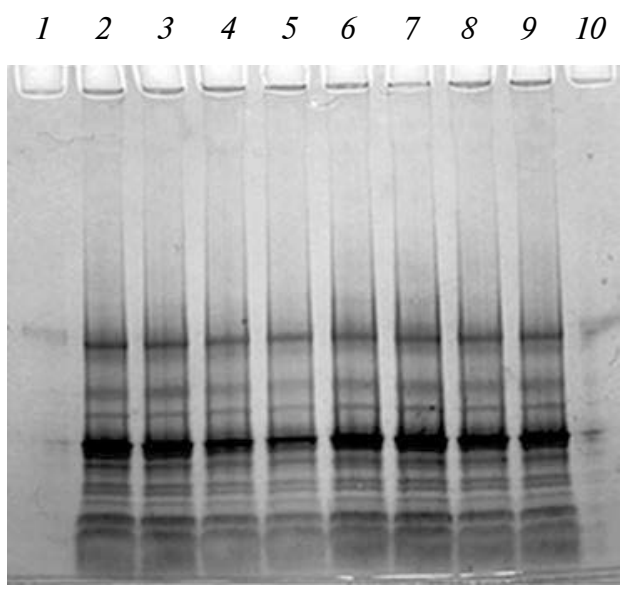

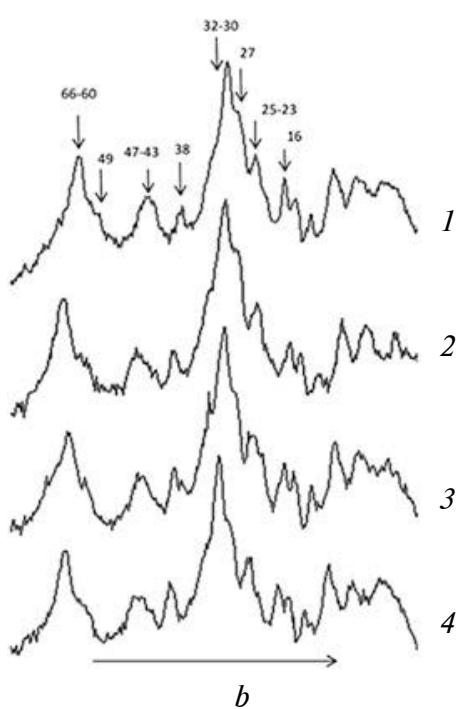

$b$

Fig. 3. The effect of inhibitors on polypeptides of pumpkin leaves $(a)$ :

1, 10-BSA marker; 2, 3- control (untreated green leaves); 4, 5- leaves after treatment 5 min $50 \mu \mathrm{M}$ methyl viologen (MV); 6, 7 - leaves restored by 16 hours after treatment 5 min $50 \mu \mathrm{M} \mathrm{MV}$ $(\mathrm{MV}+16 \mathrm{~h}) ; 8,9-$ leaves treated $5 \mathrm{~min} 50 \mu \mathrm{M} \mathrm{MV}$, then treated $5 \mathrm{~min} 10 \mathrm{mg} / \mathrm{ml}$ chloramphenicol $(\mathrm{CAP})$, and restored 16 hours $(\mathrm{MV}+\mathrm{CAP}+16 \mathrm{~h})$.

Chloroplast polypeptide profiles and densitogram from pumpkin leaves $(b)$ :

1 - control; $2-5 \min 50 \mu \mathrm{M} \mathrm{MV} ; 3-5 \min 50 \mu \mathrm{M} \mathrm{MV}+16 \mathrm{~h}$ restoration; $4-5 \min 50 \mu \mathrm{M}$ $\mathrm{MV}+5 \mathrm{~min} 10 \mathrm{mg} / \mathrm{ml} \mathrm{CAP}+16 \mathrm{~h}$ restoration

position, was quantitatively decreased (see Fig. $3 b, 2$ ). The decreasing of polypeptides at $60-66 \mathrm{kDa}$ zone was negligable. After $16 \mathrm{~h}$ adaptation after action of MV (5 min) a broadening of zone at $60-66 \mathrm{kDa}$ was observed, a peak at $49 \mathrm{kDa}$ was concentrated, and well-defined peak at $32 \mathrm{kDa}$ protein marked. The zone at $23-25 \mathrm{kDa}$ protein was enlarged and divided on 2 peaks (see Fig. $3 b, 3$ ).

Action of CAP in case of increased content in chloroplast of ROS produced by MV after $16 \mathrm{~h}$ of restoration - the decreasing of polypeptides in range of $60-66 \mathrm{kDa}$, decreasing and widening of zone $43-47 \mathrm{kDa}$ where 3 peaks is well-defined, increasing of zones at range of $30-32 \mathrm{kDa}$ (see Fig. 3b, 4).

For elucidation of dependence of PSII activity from changes of polypeptides, especially at region of main protein of PSII $\left(D_{1}\right.$ protein) under oxidative stress a Fig. 4 is presented by us. The restoration processes, delayed by CAP action also will assist to establishment of this dependence.

TABLE 2. Quantitative changes in protein zones in the ranges of $43-47 \mathrm{kDa}$ and $30-32 \mathrm{kDa}$ : 1, 2 - control (untreated green leaves); 3, 4 - leaves after treatment $5 \mathrm{~min} 50 \mu \mathrm{M}$ methylviologen $(M V) ; 5,6$ - leaves restored 16 hours after treatment $5 \mathrm{~min} 50 \mu M M V(M V+16$ h); 7, 8 - leaves treated $5 \mathrm{~min} 50 \mu \mathrm{M} \mathrm{MV}$, then treated $5 \mathrm{~min} 10 \mathrm{mg} / \mathrm{ml}$ chloramphenicol and restored 16 hours $(M V+C A P+16 h)$

\begin{tabular}{l|c|c|c|c|c|c|c|c}
\hline Protein zones & 1 & 2 & 3 & 4 & 5 & 6 & 7 & 8 \\
\hline $43-47 \mathrm{kDa}$ & 135.8 & 135.79 & 110.5 & 108.06 & 127.47 & 138.71 & 132.04 & 137.33 \\
$30-32 \mathrm{kDa}$ & 185.30 & 148.98 & 138.28 & 124.67 & 143.45 & 155.75 & 144.34 & 161.20 \\
\hline
\end{tabular}




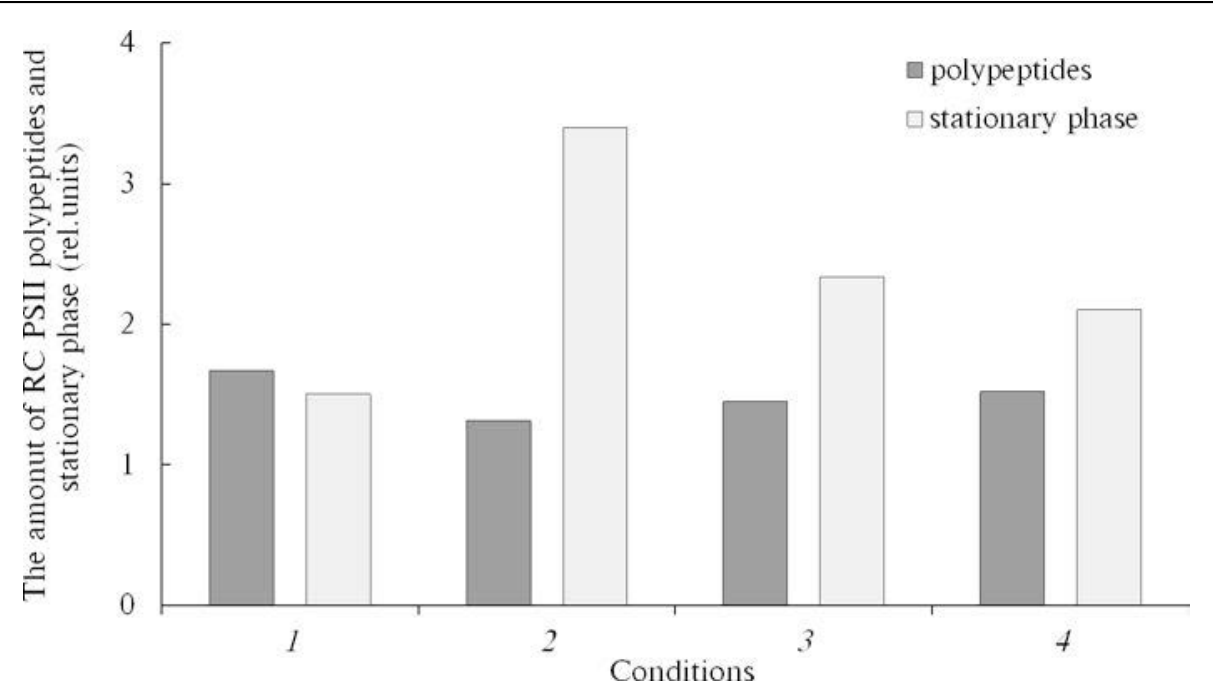

Fig. 4. Changes of the $30-32 \mathrm{kDa}$ polypeptides (relative amount of polypeptides related to reaction center of PSII ( $\mathrm{D}_{1}$ protein) (see Fig. $3 a$ ) and msec-DF Chl $a\left(\mathrm{P}^{2} 80^{*}+\mathrm{Q}_{\mathrm{A}} \rightarrow \mathrm{Q}_{\mathrm{B}}\right)$ during the oxidative stress caused with treatment $50 \mu \mathrm{M}$ methyl viologen (MV) 5 min:

1 - control (untreated green leaves); 2 - leaves after treatment by $50 \mu \mathrm{M}$ MV at $5 \mathrm{~min} ; 3$ - leaves restored by 16 hours after treatment $5 \min 50 \mu \mathrm{M}$ MV (MV+16 h); 4 - leaves treated by $50 \mu \mathrm{M}$ MV during $5 \mathrm{~min}$, then $5 \mathrm{~min}$ with $10 \mathrm{mg} / \mathrm{ml}$ chloramphenicol, and restored 16 hours $(\mathrm{MV}+\mathrm{CAP}+16 \mathrm{~h}$ )

On the Fig. 4, 1 the dependence of PSII activity state from polypeptides changes especially at range of main protein of PSII $-\mathrm{D}_{1}$ under oxidative stress generated by MV. The sharp increase of stationary fluorescence (see Fig. 4, 2) and definite fall of value proportional to level of $D_{1}$ protein indicate the formation of reactive oxygen species.

The restoration processes (16 h after action of MV (Fig. 5)) are characterized by some increase of polypeptide at zone 30-32 kDa and fall of stationary fluorescence (see Fig. 4, 3), that is evident about increasing of

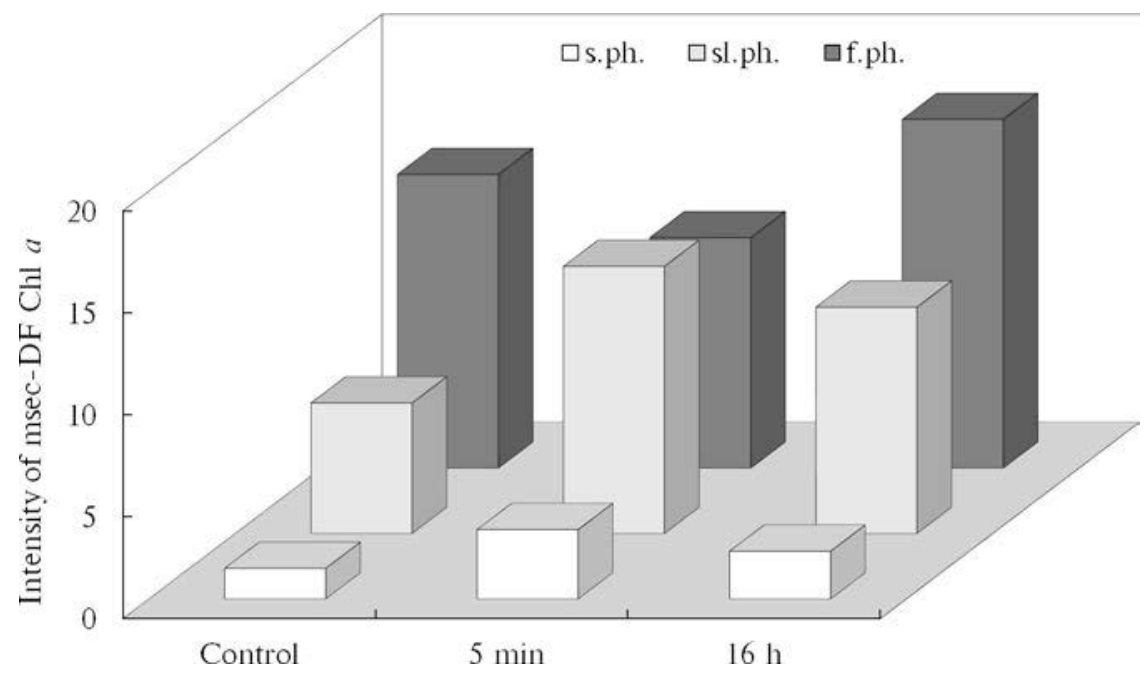

Fig. 5. Changes of delayed fluorescence of steady state (s.ph.), slow (sl.ph.) and fast (f.ph.) phases in control, after treatment $5 \mathrm{~min}$ by MV and after washing off MV $16 \mathrm{~h}$ of restoration 


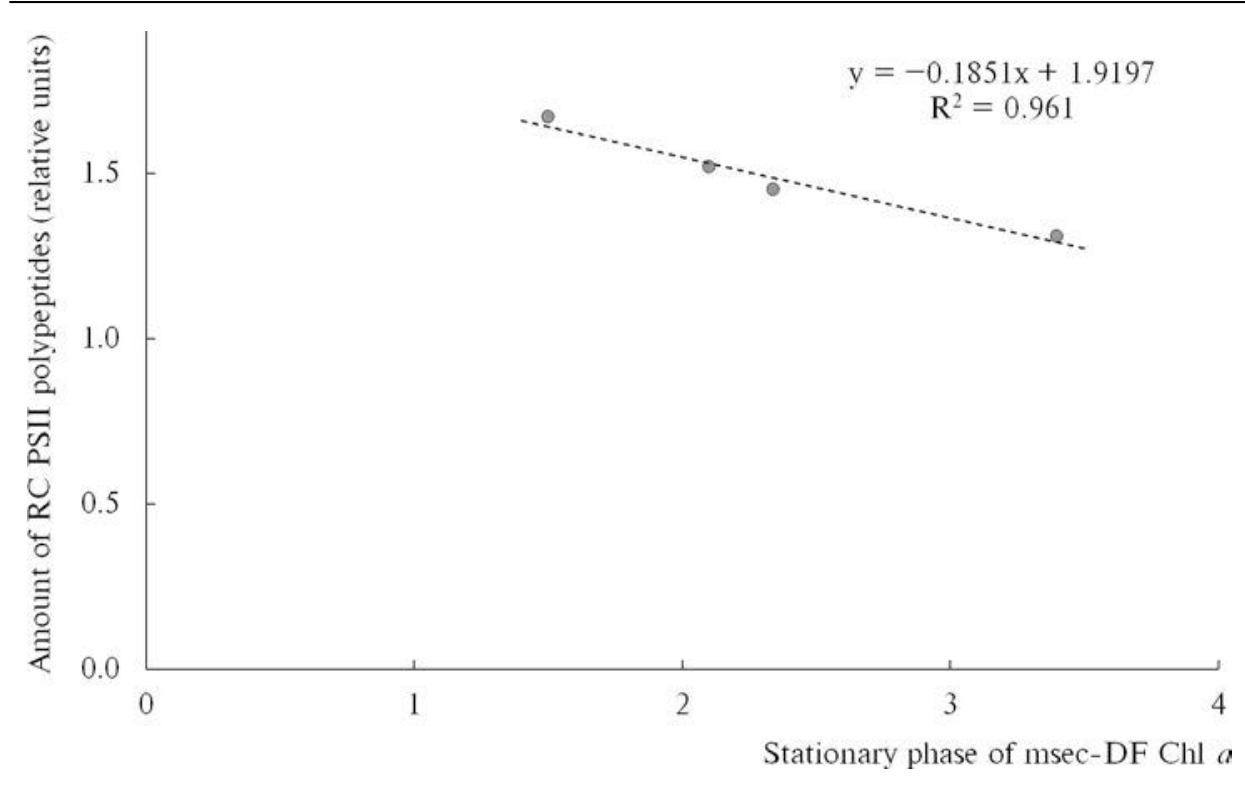

Fig. 6. Correlation between the average values of the PSII reaction centers (obtained from the average density of polypeptides at $32-33 \mathrm{kDa}$ ) and the intensity of the stationary phase (s.ph) Chl $a$ msec-DF (relative units)

electron transfer on acceptor side of PSII ETC. The introduction to system of protein synthesis inhibitor CAP significantly affects on occurred changes, characterized PSII activity (see Fig. 4, 4).

The Fig. 6 represents correlation plot of relative amount of polypeptides related to RC (reaction center) PSII (probably proportional to $\mathrm{D}_{1}$ protein) upon the steady state level (s.ph) of induction curve of msec-DF of Chl $a$, during oxidative stress in leaves of pumpkin induced by action of MV and restoration process under different conditions.

We can approximate it with line function and find strong enough reverse correlation between these two parameters with Pearson coefficient $\mathrm{R}^{2}=0.961$. With increasing of the relative amount of polypeptides associated to RC PSII during 16-hours restoration (see Fig. 3 and Fig. 4), level of stationary phase intensity decreasing sharply. We suppose that this is due to the turnover at $\mathrm{D}_{1}$ protein during restoration of pumpkin leaves and recovery equilibrium between PSII activity and synthesis of new protein of PSII reaction centers.

The CAP and MV inactivated processes connected with capture and charge separation with formation of initial radical pair P680*Phe (f.ph.) and electron transfer on primary quinine acceptor $\mathrm{Q}_{\mathrm{A}}$ (sl.ph.). The chloramphenicol action to these processes was less aggressive relatively to action of MV. The sharp increase of stationary fluorescence and sharp fall of value polypeptides, probably proportional to $\mathrm{D}_{1}$ protein level indicate significant influence of MV to structural changes and activity of PSII ETC. The MVproduced ROS damaged PSII in vivo, strong reactive forms ${ }^{1} \mathrm{O}_{2}$ and $\mathrm{OH}^{-}$ has inhibited whole restoration of damaged PSII [3]. The effect of CAP is similar with effect of MV but less aggressively suppressed of msec-DF $\mathrm{Chl} a$ parameters. At the case of CAP action the steady state level of DF say about preservation of oxidative-stationary equilibrium between photo- 
systems. Probably CAP leads to suppression of $\mathrm{D}_{1}$ protein formation $d e$ novo, breaked by oxidative stress, and disturbance of equilibrium between RC PSII inactivation and synthesis of new centers.

\section{REFERENCES}

1. Alonso, Z., Mun, H.C., Warwick, H., Wah, S.C. \& Shunichi, T. (2015). Photodamage to the oxygen evolving complex of photosystem II by visible light. Sci. Rep., 5, p. 16363. https://doi.org/10.1038/srep16363

2. Baishnab, C.T. \& Ralf, O. (2012). Reactive oxygen species generation and signaling in plants. Plant Signaling \& Behavior, 7 (12), pp. 1621-1633. https://doi.org/10.4161/ psb. 22455

3. Jafarova, J., Ganiyeva, R., Bayramova, S. \& Gasanov, R. (2019). The nature of PSII reactions stability under oxidative stress. Bangladesh J. Bot., 48 (4), pp. 1029-1035. https://doi.org/10.3329/bjb.v48i4.49051

4. Ganiyeva, R.A., Kurbanova, I.M. \& Dadasheva, S.B. (2000). Fluorescence of chlorophyll and polypeptide composition of thylakoids under action of $\mathrm{NaCl}$ and polyethyleneglycol on wheat seedlings. Physiology and biochemistry of cultured plants, 32 (4), pp. 273-278.

5. Ganieva, R.A. \& Kurbanova, I.M. (2007). Stabilization of photosynthetic membranes by polystymuline $\mathrm{K}$ under salt stress conditions. Physiology and biochemistry of cultured plants, 39 (4), pp. 303-310.

6. Gasanov, R.A., Alieva, S., Arao, S., Ismailova, A., Katsuta, N., Kitade, H., Yamada, Sh., Kawamori, A. \& Mamedov, F. (2007). Comparative study of the water oxidizing reactions and the millisecond delayed chlorophyll fluorescence in photosystem II at different $\mathrm{pH}$. J. of Photochem. Photobiol., 86, pp. 160-164. https://doi.org/10.1016/j.jphotobiol.2006.08.008

7. Gaziyev, A., Aliyeva, S., Kurbanova, I., Ganiyeva, R., Bayramova, S. \& Gasanov, R. (2011). Molecular operation of metals into the function and state of photosystem II. Metallomics, 3 (12), pp. 1362-1367. https://doi.org/10.1039/C1MT00100K

8. Nishiyama, Y., Allakhverdiev, S. \& Murata, N. (2011). Protein synthesis is the primary target of reactive oxygen species in the photoinhibition of photosystem II. Physiol. Plant, 142, pp. 35-46. https://doi.org/10.1111/j.1399-3054.2011.01457.x

9. Oguchi, R., Terashima, I. \& Chow, W.S. (2021). The effect of different spectral light quality on the photoinhibition of Photosystem I in intact leaves. Photosynthesis Research, 149, pp 83-92. https://doi.org/10.1007/s11120-020-00805-z

10. Pathak, Vinay, Prasad, A. \& Pospisil, P. (2017). Formation of singlet oxygen by decomposition of protein hydroperoxide in photosystem II. PLoS One, 12 (7), p. e0181732.

11. Kodru, S., Rehman, A. \& Vass, I. (2020). Chloramphenicol enhances Photosystem II photodamage in intact cells of the cyanobacterium Synechocystis PCC 6803. Photosynthesis Research, 145, pp. 227-235. https://doi.org/10.1007/s11120-020-00784-1

12. Kolupaev, Yu.E. \& Kokorev, A.I. (2019). Antioxidant system and plant resistance to water deficit. Fiziol. rast. genet., 51 (1), pp. 28-54. https://doi.org/10.15407/ frg2019.01.028

13. Pavel, P. (2016). Production of Reactive Oxygen Species by Photosystem II as a Response to Light and Temperature Stress. Front Plant Sci., 7, p. 1950.

14. Rantala, S., Järvi, S. \& Aro, E.-M. (2021). Photosynthesis | Photosystem II: Assembly and Turnover of the Reaction Center D1 Protein in Plant Chloroplasts. Encyclopedia of Biological Chemistry III (Third Edition), pp. 207-214. https://doi.org/10.1016/B978-012-809633-8.21404-0

15. Renger, G. \& Renger, T. (2008). Photosystem II: the machinery of photosynthetic water splitting. Photosynthesis Research, 98,(1-3), pp. 53-80. https://doi.org/10.1007/s11120008-9345-7

16. Takahashi, Sh. \& Murata, N. (2008). How do environmental stresses accelerate photoinhibition. Trends Plant Sci., 13 (4), pp. 178-182. https://doi.org/10.1016/ j.tplants.2008.01.005

17. Takahashi, Sh. \& Badger, M.R. (2010). Photoprotection in plants: a new light on photosystem II damage. Trends Plant Sci., 16 (1), pp. 53-60. https://doi.org/10.1016/ j.tplants.2010.10.001 
18. Vass, I. \& Cser, K. (2009). Janus-faced charge recombinations in photosystem II photoinhibition. Trends Plant Sci., 14, pp. 200-205. https://doi.org/10.1016/ j.tplants.2009.01.009

19. Vass, I. (2012). Molecular mechanisms of photodamage in the Photosystem II complex. Biochim. Biophys. Acta, 1817, pp. 209-217. https://doi.org/10.1016/j.bbabio.2005.04.003

Received 10.09.2021

\title{
СТРУКТУРНА ТА ФУНКЦІОНАЛЬНА ЗАЛЕЖНІСТТЬ АКТИВНОСТІ ФС II ЗА ОКИСНЮВАЛЬНОГО СТРЕСУ
}

\author{
Д. Джафарова ${ }^{1}$, Р. Ганієва ${ }^{1}$, Л. Мамедова ${ }^{2},{\text { Р. } \text { Агаларов }^{2}, \text { Р. Гасанов }}^{2}$ \\ ${ }^{1}$ Їнститут ботаніки Національної академії наук Азербайджану, Баку \\ ${ }^{2}$ Біотехнологічна лабораторія, кафедра біофізики та молекулярної біології \\ Бакинського державного університету \\ e-mail: j.jafarova@yahoo.com
}

\begin{abstract}
Дія метилвіологену (MB) на листок гарбуза (Cucurbita pepo L.) збільшила вміст активних форм кисню (АФК), що спричинило порушення електронтранспортного ланцюга ФС II. Після обробки МВ проростки були оброблені інгібітором синтезу білка - хлорамфеніколом (ХФ). Аналіз кривих індукції флуоресценції Хл $a 3$ мілісекундною затримкою (мс-ЗФ Хл $a$ ) показує зміну інтенсивності фази мс-ЗФ Хл $a$, можливо, в результаті інгібування утворення білка $\mathrm{D}_{1}$ de novo. Спостерігали зміни профілів білків, особливо у вмісті поліпептидів ФС II у хлоропластах залежно від дії метилвіологену та ХФ. Показано тісну кореляцію між змінами поліпептидів ФС II та зміною стаціонарної фази мс-ЗФ Хл $a$.
\end{abstract}

Ключові слова: Cucurbita pepo L., окисне пошкодження, мілісекундна затримка флуоресценції Хл $a$, активні форми кисню, метилвіологен. 